\section{共享空间与宜居生活一一新加坡实践经验 \\ SHARING SPACE AND LIVEABLE LIFE IN SINGAPORE PRACTICES}

摘要

近年来，共享经济所引发的变革对城市空间和人们的生活 方式产生了深远的影响。快速的城镇化进程和人口的急剧扩张 使得城市中挑战与机遇并存, 因而叒待构建一个周密详尽的社 会规划和管理体系来应对这一问题。新加坡是亚洲地区少有的 在高密度前提下仍然能够达到高宜居标准的城市范例。笔者通 过策略回顾和案例研究, 展示了新加坡在城市宜居性和可持续 发展方面的实践经验，并提出决策制定、空间规划和场地管理 三个关键议题。该研究有助于在共享城市发展的新纪元推动实 施各项可改善公共健康状况和提高生活品质的策略。

关键词

共享空间; 宜居性; 综合发展; 新加坡

\section{ABSTRACT}

In recent years, the revolution brought by sharing economy has significantly shaped the urban space and lifestyles. Cities face both huge challenges and great opportunities in the rapid urbanization and population aggregation, which depends on a well-planned and -governed human society. Singapore is one of few high-dense cities that are able to achieve high liveable standards in the Asian context. The authors reveal the Singapore practices on urban liveability and sustainable development via strategy review and case study, which addresses three key issues in policy-making, spatial arrangement, and site management. This research contributes to facilitating the implementation of public health promotion and quality life improvement in the new era of sharing city.

\section{KEY WORDS}

Sharing Space; Liveability; Integrated Development; Singapore 


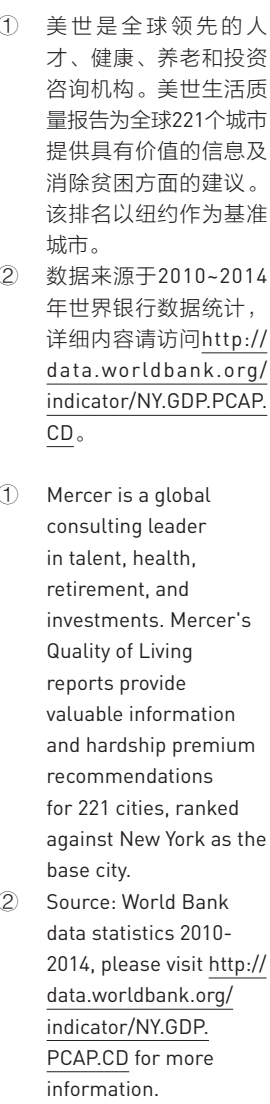

Mercer is a global consulting leader in talent, health retirement, and investments. Mercer's Quality of Living reports provide valuable information and hardship premium recommendations for 221 cities, ranked against New York as the against New York as the

Source: World Ban data statistics 20102014, please visit http:// data.worldbank.org/ indicator/NY.GDP. PCAP.CD for mo information.

\section{1 引言}

近年来，共享经济所引发的变革对城市空间和人们的生活方式产 生了深远的影响。快速的城镇化进程和人口的急剧扩张使得城市中挑 战和机遇并存, 因而亟待构建一个周密详尽的社会规划和管理体系来 应对这一问题 ${ }^{[1]}$ 。共享城市的关键挑战在于如何驱动和连接共享空间、 资源和设施，以满足城市宜居性和可持续发展要求。可持续性是指在 使当代人享有合理生活水平的同时，亦不损害子孙后代的利益；而宜 居性则强调在当前以紧凑城市形态为基础的环境状况下, 提供较高品 质的都市生活 ${ }^{[2]}$ 。宜居性的评价标准涉及健康、教育、收人、个人价 值和社会环境等方面 ${ }^{[3]-[5]}$ 。城市中的高品质生活意味着人们可获取商 品和服务, 享受便利的社会基础设施、优美的自然环境, 且有充足的 机会去实现有价值、有意义的生活。本文中笔者侧重于讨论与场地相 关的问题，在场地中，公众可以去参与、体验，并从使用空间的过程 中获益。

在2012 2017年的美世生活质量调查 ${ }^{\circledR}$ 中，以中等规模城市、低密 度人口和高品质建成环境为特征的位于欧洲、北美和大洋洲的城市持 续占据着排名的前 10 位 $^{[6]}$ 。新加坡在亚洲城市中位居榜首, 是极少数在 高密度条件下，依旧能够达到高宜居标准并实现可持续发展的城市 之一 ${ }^{[7]}$ 。这个城邦国家是如何在有限的土地资源和众多人口的情况 下获此殊荣的呢? 在新加坡, 经济发展和环境性能显著相关, 且相 互促进 ${ }^{[8] 19]}$ 。自1963年以来, 新加坡启动了花园城市项目, 作为与经济 和社会发展相关的国家建设政策，保障了自然保育和社会发展井然有 序 ${ }^{[10]}$ 。新加坡前总理李光耀将花园城市项目视作最值得骄傲的遗产, 因其将新加坡从第三世界带人了第一世界的行列 ${ }^{[11]}$ 。热爱自然的天性 来源于人类与自然的固有联系 ${ }^{[12]}$, 是热带气候条件下用以构建充满活 力、蓬勃发展的生活和工作环境的积极要素和催化剂。以城市和自然 的共生为基础, 自 20 世纪60年代取得独立后, 新加坡经历了高速的经 济发展，自2011年以来，其人均国内生产总值已超过5万美元 ${ }^{2}$ 。新加 坡宜居城市中心 ( CLC) 和公共服务学院 ( CSC ) 共同提出了 “新加

\section{Introduction}

In recent years, the revolution brought by sharing economy has significantly shaped the urban space and lifestyles. Cities face both huge challenges and great opportunities in the rapid urbanization and population aggregation, which depends on a well-planned and -governed human society ${ }^{[1]}$. The crucial challenges of sharing cities are converging to drive and link the shared spaces, resources, and facilities to promote urban liveability and sustainable development. While sustainability calls for a decent standard of living for everyone today without compromising the needs of the future generations; liveability focuses on affording an acceptable quality of life in the current context of compact urban morphology $y^{[2]}$. The impact criteria of liveability include health, education, income, personal fulfilment, and social conditions, etc. ${ }^{[3] \sim[5]} \mathrm{A}$ city that experiences a high quality of life has access to goods, services, social infrastructure, natural environment, and sufficient opportunities for a fulfilling and meaningful life. The authors focus on the issues tied to urban places, where the public could engage, experience, and acquire benefits from making use of the space.

In the Mercer Quality of Living Survey ${ }^{(1)} 2012$ to 2017, cities from Europe, North America, and Oceania continue to dominate the top 10 of the ranking by the general criteria of medium-sized urban areas, low dense populations, and high quality of built environment ${ }^{[6]}$. Singapore ranks the top of Asian cities and is one of few high-dense cities that are able to achieve high liveable standards and sustainable development ${ }^{[7]}$. How could such a city-state be granted a prominent honor under a limited land resource and a large population? In Singapore, the economic development and environmental performance are significantly interrelated and mutually stimulated ${ }^{[8][9]}$. Since 1963, Singapore has launched the Garden City project as a state-building policy with economic and social relevance for disciplining nature and society ${ }^{[10]}$. The former Prime Minister Lee Kuan Yew regarded the Garden City project as the proudest legacies which brought Singapore from the Third World to the First World ${ }^{[11]}$. Biophilia, the inherent connection between human and nature ${ }^{[12]}$, serves as a positive ingredient as well as a catalyst for vibrant and dynamic living and working habitat to flourish in a tropical environment. Grounded on the urban nature symbiosis, Singapore experienced a rapid economic development after independence in the 1960s and the GDP per capital achieved 50,000 USD since $2011^{2}$. Center for Livable Cities (CLC) and Civil Service College (CSC) have developed a Singapore Liveability Framework ${ }^{[13]}$, which regards that a 
坡宜居框架” ${ }^{[13]}$, 其认为具有竞争力的经济、可持续的环境和高品质 的生活是构建宜居城市的三个重要组成部分。依赖于城镇化进程中经 济、社会和环境的均衡发展, 新加坡才得以兼容高密度的城市基础设 施和高品质的宜居生活水准（图1）。

\section{2 新加坡实践}

\section{1 战略回顾}

自1963年开展 “花园城市” 绿化运动以来, 经过数十年的发展, 新加坡已成为 “花园中的城市” , 构建了由自然景观与高层建筑相结 合的垂直绿化生活典范 ${ }^{[14]}$ 。针对快速增长的人口和有限的土地, 新加 坡政府有着长远的规划。2013年, 国家人口及人才署出版了《新加坡 人口白皮书》, 目标是在 2030 年建成一个可持续发展的、充满活力的 新加坡。据估计，2020年新加坡居民和非居民总人口将达到约600万， 2030 年总人口可达到650 690 万 ${ }^{[15]}$ 。人口可持续发展的核心问题在于如 何在缓解老龄化社会的消极影响的同时, 提高城市环境的宜居性。这 competitive economy, a sustainable environment, and a high quality of life are the three key components of the national policy to support the urban liveability for Singapore. Based on the balanced development of urbanization in the economy, society and environment, Singapore has integrated highdense urban infrastructure with high quality of living standards (Fig. 1).

\section{Singapore Practices}

\subsection{Strategy Review}

Singapore started the "Garden City" greening campaign since 1963. Over the decades, Singapore becomes "a city in a garden" which established an exemplary example of vertical green living composed of high-rise buildings surrounded by greenery and landscapes ${ }^{[14]}$. The Singapore government has a long-term plan for the fast growth population and the limited land resource. In 2013, the National Population and Talent Division published Singapore Population White Paper with the target to build a sustainable, dynamic Singapore in 2030. It is predicted that Singapore's total population including city dwellers and immigrants, by 2020 is projected to be around 6 million, while by 2030, Singapore's total population could range between 6.5 and 6.9 million $^{[15]}$. The core issue in the sustainable development relies on the balance between alleviating the negative impact of greying society and the

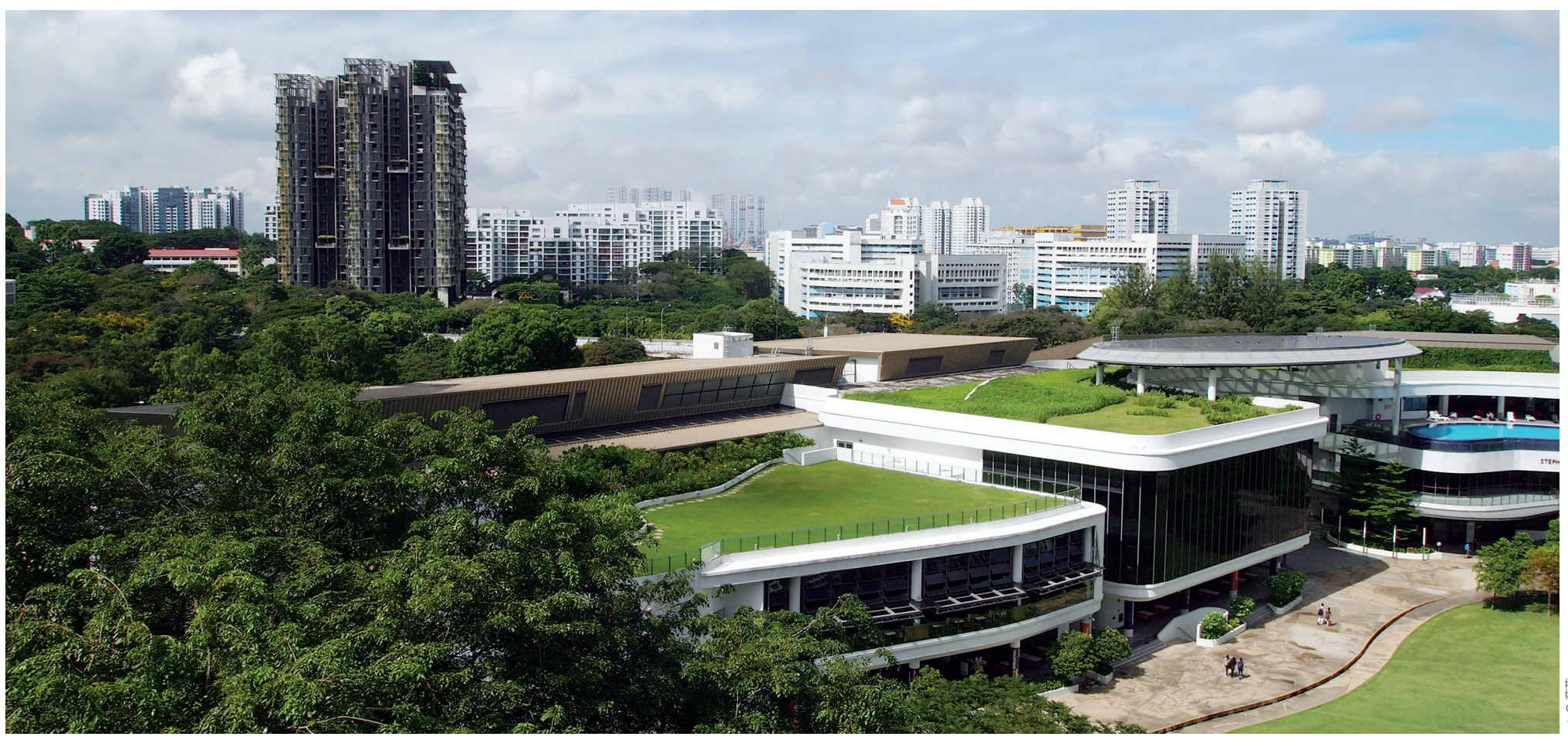




\begin{tabular}{|c|c|c|}
\hline $\begin{array}{c}\text { 分类 } \\
\text { Categories }\end{array}$ & $\begin{array}{c}\text { 现状 } \\
\text { Current Achievements }\end{array}$ & $\begin{array}{c}\text { 未来规划 } \\
\text { Future Plans }\end{array}$ \\
\hline $\begin{array}{l}\text { 城市公共空间和绿色网络 } \\
\text { Urban Open Space and } \\
\text { Green Networks }\end{array}$ & $\begin{array}{l}\text { 每千人平均公园面积为 } 0.8 \mathrm{hm}^{2} ; \\
\text { 公园连道长为 } 200 \mathrm{~km} ; \\
\text { 公园数量超过 } 350 \text { 个; } \\
\text { 已建立面积约 } 800 \mathrm{hm}^{2} \text { 的水库和长约 } 80 \mathrm{~km} \text { 水道用于休闲活动。 } \\
0.8 \mathrm{hm}^{2} \text { of parks per } 1,000 \text { residents; } \\
200 \mathrm{~km} \text { park connectors; } \\
\text { More than } 350 \text { parks; } \\
\text { About } 800 \mathrm{hm}^{2} \text { of reservoirs and } 80 \mathrm{~km} \text { of waterways already built-up for recreational } \\
\text { activities. }\end{array}$ & $\begin{array}{l}\text { 截至2030年, } 85 \% \text { 以上的居民及其家庭将生活在距公园 } 400 \mathrm{~m} \text { 以内; } \\
\text { 截至2020年, 公园连道将长达 } 360 \mathrm{~km} \text {; } \\
\text { 为环岛提供长达 } 150 \mathrm{~km} \text { 的不间断的休闲路线; } \\
\text { 截至2030年, 将开放面积达 } 900 \mathrm{hm}^{2} \text { 的水库和长达 } 100 \mathrm{~km} \text { 的水道用于休闲活动。 } \\
\text { At least } 85 \% \text { of residents and their families can live within } 400 \text { distance from a park by 2030; } \\
360 \mathrm{~km} \text { of park connectors by } 2020 \text {; } \\
\text { Will provide a } 150 \mathrm{~km} \text { uninterrupted leisure route around the island; } \\
\text { About } 900 \mathrm{hm}^{2} \text { of reservoirs and } 100 \mathrm{~km} \text { of waterways will be open for recreational activities } \\
\text { by 2030; }\end{array}$ \\
\hline $\begin{array}{l}\text { 空中绿化创新实践 } \\
\text { Skyrise Greenery } \\
\text { Innovation and } \\
\text { Implement }\end{array}$ & $\begin{array}{l}\text { 国家公园局推出了 “空中绿意津贴计划”，以鼓励屋顶绿化和垂直绿化; } \\
\text { 市区重建局推出的 “打造翠绿都市和空中绿” ( LUSH) 计划推动了私有发展项目中的 } \\
\text { 垂直绿化和空中绿化, 截至目前, 经其扶持的新型高层建筑和城市绿化面积达 } 40 \mathrm{hm}^{2} 。 \\
\text { The National Parks Board has introduced the Skyrise Greenery Incentive Scheme } \\
\text { to provide funding for the installation of green roofs and vertical greenery on building } \\
\text { facades; } \\
\text { Landscaping for Urban Spaces and Highrises (LUSH) Program by the Urban } \\
\text { Redevelopment Authority promotes more vertical and skyrise greenery in private } \\
\text { developments, which has supported the development of } 40 \mathrm{hm}^{2} \text { of new high-rise and } \\
\text { urban greenery to date. }\end{array}$ & $\begin{array}{l}\text { 空中绿意津贴计划和LUSH计划将确保未来城镇化进程中的绿化覆盖水平, 绿化区可由园景 } \\
\text { 区、空中露台和屋项花园共同组成。 } \\
\text { The Skyrise Greenery Incentive Scheme and the LUSH Program will ensure the greenery } \\
\text { coverage to be maintained in the future urbanization, and the greenery can be provided } \\
\text { through a combination of landscaped areas, sky terraces, and rooftop gardens. }\end{array}$ \\
\hline $\begin{array}{l}\text { 自然遗产保护 } \\
\text { Natural Heritage } \\
\text { Conservation }\end{array}$ & $\begin{array}{l}\text { 当前在 } 4 \text { 个自然保护区和 } 18 \text { 个自然区域中保存着重要且具代表性的地方生态系统。 } \\
\text { Conserve a significant and representative local ecosystem in four natural reserves and } \\
18 \text { natural areas. }\end{array}$ & $\begin{array}{l}\text { 未来将新增 } 10 \% \text { 左右的土地用于绿化。 } \\
\text { There will be around } 10 \% \text { of the land to greenery in the future. }\end{array}$ \\
\hline $\begin{array}{l}\text { 可步行性和短途自行车道 } \\
\text { Walkability and Cycling } \\
\text { for Short Distance } \\
\text { Transport }\end{array}$ & 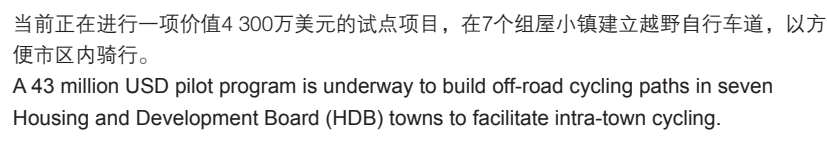 & $\begin{array}{l}\text { 长远计划是将越野自行车网络扩展到全岛尽可能多的地方, 利用广泛的公园连道网络, 构建 } \\
\text { 范围更广、更安全的自行车网络。 } \\
\text { The long-term plan is to extend the off-road cycling network as much as possible, } \\
\text { capitalising on the extensive Park Connector Network to achieve a larger and safer cycling } \\
\text { network. }\end{array}$ \\
\hline
\end{tabular}

来源：《可承载新加坡未来人口的土地利用规划》( 2013年)

Source: Land Use Plan to Support Singapore's Future Population, 2013

一关键问题更引发了人们对于如何为下一代的发展制定更具效率和效 力的土地利用规划的思考。其核心原则是通过扩大和优化土地利用来 创造新的土地产能, 以满足长期的宜居性需求。白皮书所提出的战略 性原则包括：1）优化现有土地利用；2）开拓更多土地；3）扩展地 下空间 ${ }^{[16]}$ 。据《2015年永续新加坡发展蓝图》所述，预计到2030年， 新加坡绿化面积将达 $328.7 \mathrm{~km}^{2}$ ，约占新加坡土地面积的 $46.3 \%$; 空中 绿化面积将达 $200 \mathrm{hm}^{2}$; 自然廊道长度将达到 $180 \mathrm{~km}^{[17]}$ 。新加坡的土地 使用政策实现了在高密度建成环境中最大限度地构建自然栖息地和进 行城市绿化的目标, 有效解决了城市高密度发展和宜居性需求之间的 矛盾（表1）。 liveability of the urban environment. It has raised a critical question for their more efficient and effective land use plan for the future generation. The key principle is to expand and optimize the land use for creating new land capacity and enhancing liveability of longer-term needs. The strategies and principles include 1) optimize the use of existing land resource; 2) reclaim more land; 3) expand the underground space ${ }^{[16]}$. According to the Sustainable Singapore Blueprint 2015, the green surface area in Singapore will be up to $328.7 \mathrm{~km}^{2}$, around $46.3 \%$ of Singapore's land area; the skyrise greenery will be up to $200 \mathrm{hm}^{2}$; and the length of natural corridors will achieve 180 $\mathrm{km}$ by the year of $2030^{[17]}$. The land use policy in Singapore successfully maximizes natural habitat and urban greening amid a high-density built environment, which balanced the dilemma between high-density built environment and dwellers' liveability (Table 1). 
近年来, 生活-工作-休闲一体化已经成为新加坡城市发展过程中 最广泛采用的规划战略 ${ }^{[5]}$ 。短期和长期的综合规划发展体系成就了新加 坡的城镇化进程 ${ }^{[7]}$, 其将混合用途概念嵌人新型城市发展和市中心复兴 计划中, 构建了融工作、学习和公众参与为一体的场所, 创造了既生 机勃勃又充满智慧的社会和文化环境 ${ }^{[18]}$ 。混合用途城市环境的标准涵 盖项目多元性、交通连通性、步行适宜性, 以及绿色开放空间和公共 场所可达性等方面。从国家级概念规划到每个场地的设计准则, 新加 坡政府和主管部门始终坚持推行交通与土地综合利用、住房与公共交 通及娱乐设施配套发展、创意产业与教育型及知识型机构整合构建, 以及营造绿色和清洁环境等策略 ${ }^{[8]}$ 。

健康的建成环境包含城市互动、场地管理、设施和项目配置等综 合领域, 同时将保障人的健康作为日常生活的重要组成部分 ${ }^{[19]}$ 。在新 加坡, 住宅、工作场所、研究机构以及其他城市基础设施中配置的城
In recent years, the integration of live-work-play has become a prevailing planning strategy in Singapore urban development $t^{[5]}$. The system of integrated planning and development in the short and long-term is crucial towards a successful urbanization in Singapore ${ }^{[7]}$. The mixed-use concept is embedded in the new town development and downtown revitalization, which creates a lively, intellectual, social, and cultural environment through excellence in working, learning, and public engagement ${ }^{[18]}$. The criteria of mixed-use urban setting include diverse programs, transportation connectivity, site walkability, accessible green open spaces, and public place-making. From the national concept planning to every plot design guidelines, Singapore government and authorities always bear in mind the strategies of transport-integrated land use, housing development with public transportation and recreational programs, creative industry development integrated with educational and intellective institutes, creating green and clean environment, etc. ${ }^{[8]}$

A healthy built environment is an integrated environment encompassing the domains of urban interaction, site management, facility and program, which is supportive of

\begin{tabular}{|c|c|c|}
\hline \multicolumn{3}{|c|}{$\begin{array}{c}\text { 表2: 健康的建成环境和综合发展 } \\
\text { Table 2: Healthy Built Environment and Integated Development }\end{array}$} \\
\hline $\begin{array}{c}\text { 分类 } \\
\text { Categories } \\
\end{array}$ & $\begin{array}{l}\text { 关键问题 } \\
\text { Key Issues }\end{array}$ & $\begin{array}{c}\text { 健康建成环境的空间标准 } \\
\text { Spatial Criteria of Healthy Built Environment } \\
\end{array}$ \\
\hline \multirow[t]{2}{*}{ 城市交互作用 } & $\begin{array}{l}\text { 开放空间的交互作用 } \\
\text { Interaction in open spaces }\end{array}$ & $\begin{array}{l}\text { 绿色、开放的空间可促进人与自然、社区的连接。 } \\
\text { Green and open spaces facilitate contact with nature, as well as contact with the community. }\end{array}$ \\
\hline & $\begin{array}{l}\text { 街道和社区的交互作用 } \\
\text { Interaction on streets and in the neighbourhood }\end{array}$ & $\begin{array}{l}\text { 区域尺度的城市结构和小尺度的建筑设计均会对街道和街区产生偶发的交互作用。 } \\
\text { Both regional scale urban structure and micro scale building design influence incidental interaction on streets and in neighbourhoods. }\end{array}$ \\
\hline \multirow[t]{3}{*}{$\begin{array}{l}\text { 场地管理和安全 } \\
\text { Site Management and } \\
\text { Security }\end{array}$} & $\begin{array}{l}\text { 安全性 } \\
\text { Safety }\end{array}$ & $\begin{array}{l}\text { 社区感和社会交往是决定社区健康的关键因素, 可确保人们所认知的社区是安全且健康的。 } \\
\text { Sense of community and social interaction are critical determinants which ensure the perception of a community is safe and } \\
\text { health. }\end{array}$ \\
\hline & $\begin{array}{l}\text { 平等性 } \\
\text { Equality }\end{array}$ & $\begin{array}{l}\text { 同等适用于老年人和残疾人。 } \\
\text { Equality for the aged and the disabled. }\end{array}$ \\
\hline & $\begin{array}{l}\text { 环境保护 } \\
\text { Environmental protection }\end{array}$ & $\begin{array}{l}\text { 控制吸烟/改善空气质量; } \\
\text { 控制噪音。 } \\
\text { Smoking / air quality control; } \\
\text { Noise control. }\end{array}$ \\
\hline \multirow[t]{3}{*}{$\begin{array}{l}\text { 设施和活动 } \\
\text { Facilities and Programs }\end{array}$} & $\begin{array}{l}\text { 便利设施 } \\
\text { Amenity facilities }\end{array}$ & $\begin{array}{l}\text { 餐厅、咖啡厅、长登、报刊亭、街头艺术、游乐场、儿童游乐场、小径等。 } \\
\text { Restaurant, café, bench, kiosk, street art, amusement park, children's playground, trail, etc. }\end{array}$ \\
\hline & $\begin{array}{l}\text { 地标和视觉连接 } \\
\text { Landmark identity and visual connection }\end{array}$ & $\begin{array}{l}\text { 视觉交流设计、地标。 } \\
\text { Visual interaction design and landmarks. }\end{array}$ \\
\hline & $\begin{array}{l}\text { 活动安排 } \\
\text { Programs }\end{array}$ & $\begin{array}{l}\text { 周末和假日安排社区活动; } \\
\text { 当地文化、遗产保护和教育体系; } \\
\text { 环境教育体系。 } \\
\text { Community activities on weekends and holidays; } \\
\text { Local cultural and heritage protection, and education system; } \\
\text { Environmental education system. }\end{array}$ \\
\hline
\end{tabular}


(3) 绿色社区标识是新加坡 建设局学院发布的绿色 评估系统, 旨在促进和 表彰那些在社区发展总 体规划、设计和实施中 体规划、设计和买施中 的环境反好型和可持㘰
性实践。

Green Mark for Districts is a green rating scheme issued by Building and Construction Authority of Singapore, which promotes and recognizes environmentally friendly and sustainable practices in master planning, design and implementation of district developments.

2. 大学城中的户外活动与城 市绿化空间

大学城中的教育资源中心

2. Outdoor activity and urban green space at UTown

3. Education Resource Center at UTown
市开放空间已实现无缝衔接。它作为一个非正式的户外起居室, 在日 常生活中起到了提升社区认同感和促进与自然互动的作用 ${ }^{[5]}$ (表 2 ）。辛西娅・卡尔森等人指出, 涉及当地经济发展和其他相关产业的 推广计划可以有效促进居民对社区步行环境的认同感 ${ }^{[20]}$ 。这种出现在 街道和公共空间的互动, 对所有人来说都是安全和可行的, 对城市和 社区场所构建有着积极效应。创造具有吸引力的户外活动 (如现场音 乐会、艺术展览、体育活动等) 和将室内项目拓展到室外空间, 都成 为鼓励公众参与和推广公共活动的有效设计策略（图2）。

\section{2 案例研究: 大学城}

新加坡国立大学大学城 ( UTown) 于2011年建成, 是一个占地 $19 \mathrm{hm}^{2}$ 的综合教育中心。由于在地区规划设计中实施了环境友好型发展 和人性化原则，该试点项目荣获新加坡建设局绿色建筑标识 ${ }^{3}$ 超金奖。 UTown将原有的高尔夫球场转变为现代化的国际校园, 保留了原有的 自然栖息地和优美地形。它通过低碳排放、自然栖息地保护和综合发 展构建了示范性的更加可持续的校园环境。在普遍的土地混合利用和 生活-工作-休闲一体化背景下, UTown最大限度地提升了空间和设施 的使用率与能产性。教育资源中心 (ERC) 是位于UTown中心位置的 教学综合楼 (图3)。ERC包含四个楼层和一个屋顶天台, 在楼内有机 people's health as part of everyday living ${ }^{[19]}$. In Singapore, urban open spaces have been seamlessly configured in residence, workplace, institutes, as well as other urban infrastructures, which perform as an informal outdoor living room for fostering a sense of community and interaction with nature in daily life ${ }^{[5]}$ (Table 2). Carlson et al. indicated the outreach programs involving awareness of local businesses and other destinations might be effective to promote the perceptions of walkability from the residents ${ }^{[20]}$. This interaction occurs on streets and in public spaces that are safe, accessible to all, responsive to the positivity effect of urban and community place-making. Attractive outdoor activities, for example, live concert, art exhibition, and sports playground, or introducing indoor programs into outdoor space, are efficient design strategies to encourage public engagement and activities (Fig. 2).

\subsection{Case Study: University Town}

The University Town (UTown) of National University of Singapore (NUS) is a 19-hectare integrated institutional hub built up in 2011. It is a pilot project awarded Building and Construction Authority (BCA) Green Mark for Districts ${ }^{(3)}$ Gold Plus, which implements environmentally friendly development and human-oriented principles into the district planning and design. UTown transforms a golf course into a modern international campus by preserving the existing natural habitat and pleasing topography. It exemplifies a more sustainable campus environment by low carbon emission, natural habitat conservation, and integrated development. Under the context
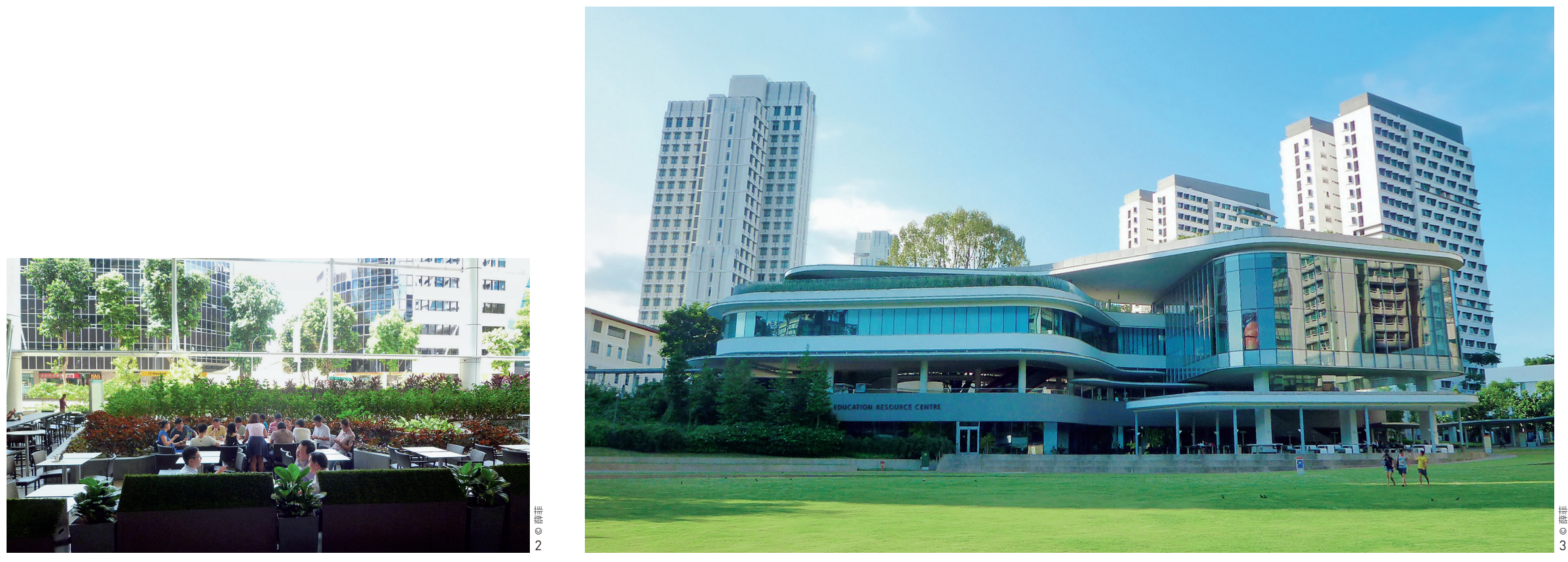
分布着学习共享空间、教室、会议室、礼堂、庭院广场和屋顶花园, 创造了用于思考、阅读、写作和其他活动的多功能场所。

ERC于 2010 年通过新加坡建设局绿色建筑标识白金认证，其设计 和建造围绕两棵树龄较长的大树展开。通过建筑围合成中央庭院绿 地, 既可保护自然环境, 也促进了人的健康。与传统的受限于封闭式 空调和人工照明系统的室内教学空间不同, ERC的布局配置了大面积 的半户外共享空间, 可支持学习、讨论和茶歇等多元活动, 创造了怡 人而灵动的舒适环境。环绕庭院绿地而设置的空间最大限度地提升了 采光效果和自然通风，全年全天候优化了空间利用率 (图4)。 of mixed-use and live-work-play integration, UTown campus demonstrates a commitment to maximize the efficiency and productivity of space and facilities. Education Resource Centre (ERC) is a learning complex located at the center of UTown (Fig. 3). ERC has four floors, and a rooftop where learning common, lecture room, seminar room, auditorium, courtyard plaza and roof garden are arranged on the organic-shaped floor plates to create multi-functional areas for break-out, reading, writing and other activities.

Certified by the BCA Green Mark Platinum in 2010, ERC was designed and built around two existing trees, which provides a green courtyard for nature conservation and human health promotion. Unlike the traditional indoor classroom confined in a closed air-conditioning and artificial lighting system, the layout of ERC creates a liveable and flexible environment by sharing a large area of semi-outdoor space for learning, discussion, tea break, etc. The space setting maximizes the daylighting, and natural ventilation surrounded the green courtyard, which optimize the space utilization in 24/7 all year around (Fig. 4).

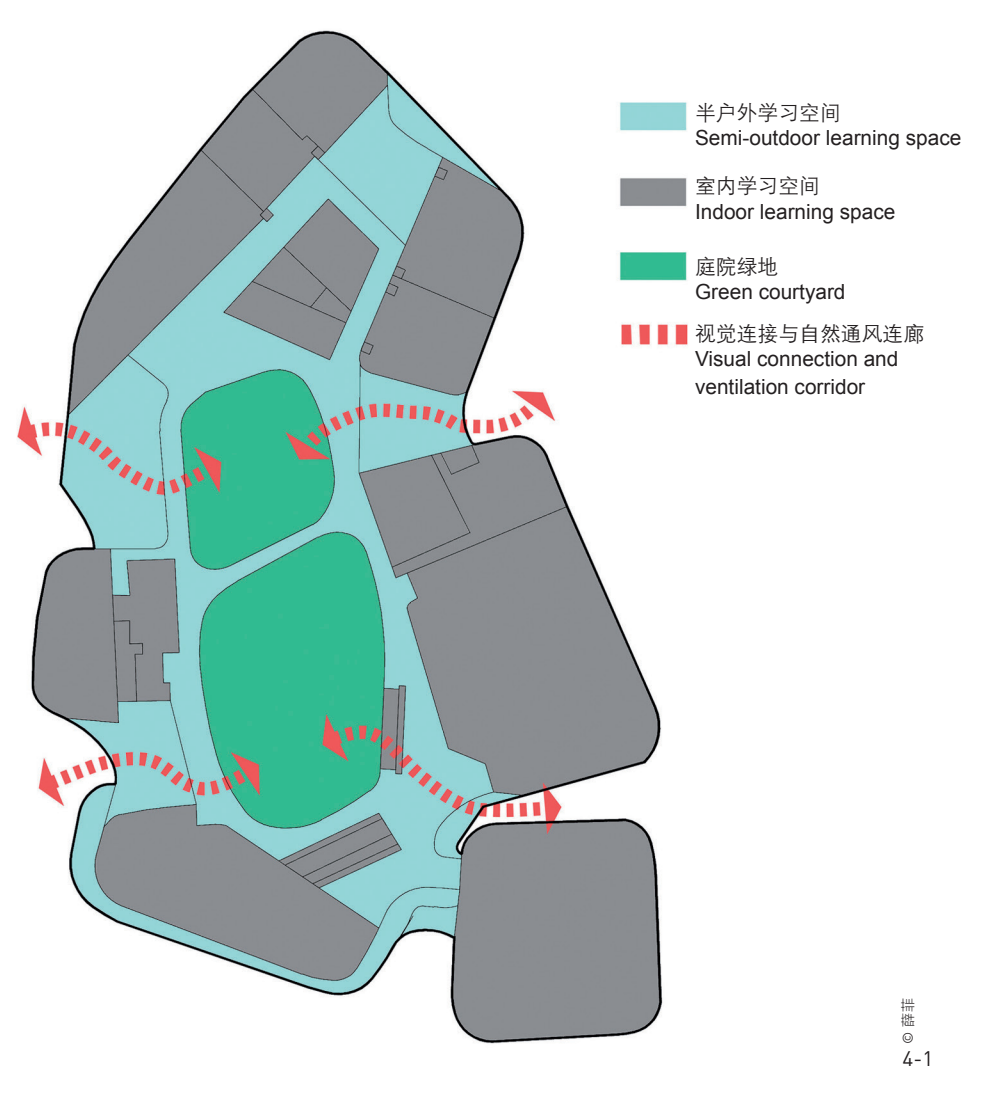

4-1. ERC的共享空间配置 4-2. 半户外学习空间

4-3. 相互联系的庭院绿地与 半户外学习空间

4-1. Sharing space at ERC 4-2. Details of semioutdoor learning space

-3. Interrelations green courtyard and semi-outdoor learning space
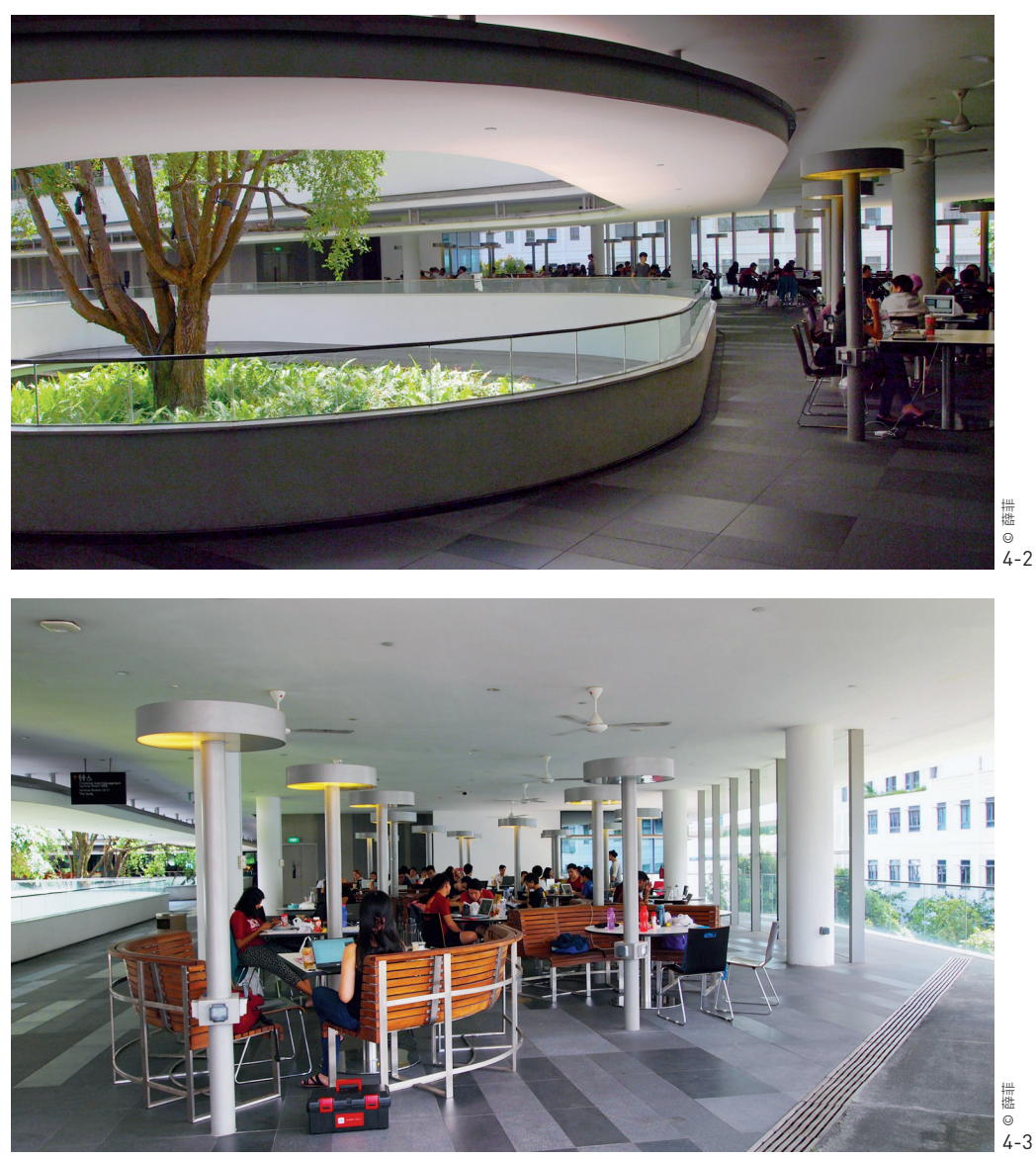
5-1. ERC中共享型商业与学 习空间

5-2. 学习咖啡馆室内空间

5-3. 半户外学习空间的延展

5-1. Sharing commercial and learning space at

5-2. Indoor space of Learning Café

5-3. The extension of semioutdoor learning space
$\mathrm{ERC}$ 对新加坡国立大学的师生及公众免费开放，一系列完善的 配套项目和设施为其吸引了大量访客。位于一楼的学习咖啡馆正对 UTown的中心绿肺, 是进行社交互动和学术探讨的最佳场所。学习咖 啡馆由两个相连的部分组成（图5)：第一部分是室内商业空间，配有 销售柜台、舒适的桌椅、舒缓的音乐和空调设施; 第二部分是延展的 半户外多功能空间, 全天候向公众开放, 配有多功能桌椅、风扇和照 明设施。这两个部分均覆盖无线信号和大量电源插座, 便于学习和工 作之用。该项目贯彻了将商业空间与学习空间相结合的设计策略，展 示了新加坡国立大学向校内人员和社会大众分享教育资源和设施的开 放态度。这一举措成功创造了一个充满活力的全天候开放式校园, 并 实现了空间和设施利用率的最大化。

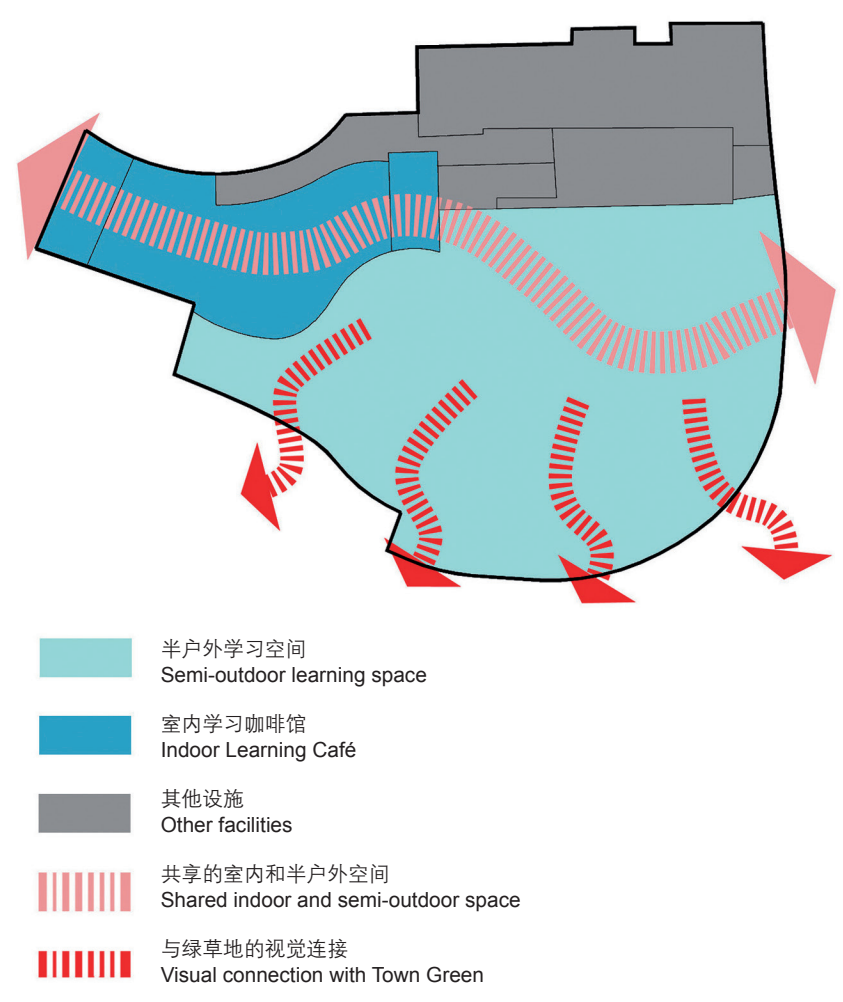

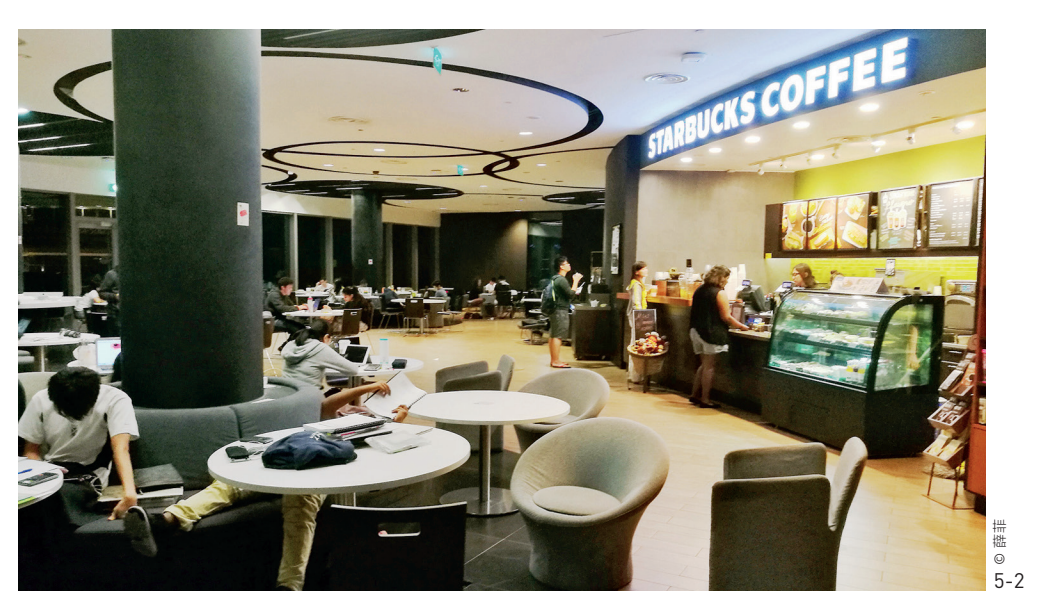

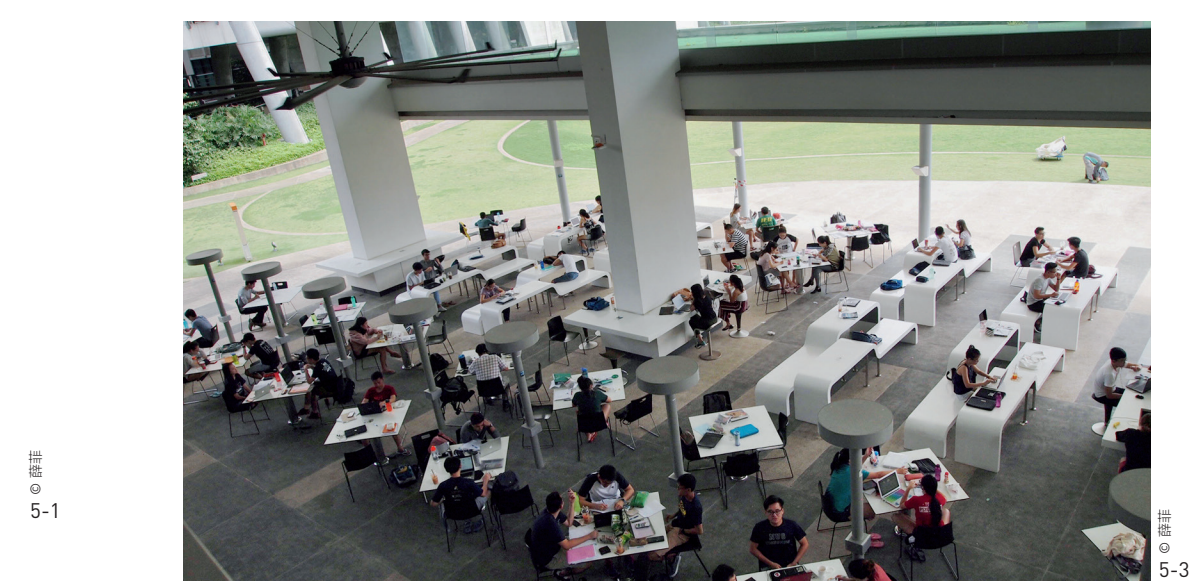

Open to the NUS and the public community, ERC attracts occupants with a sequence of supporting program and facilities. There is a Learning Café located on the ground floor, which faces to the central Town Green and creates the best place for social interaction and intellectual discussion. The Learning Café comprises of two connected sectors (Fig. 5). The first sector is an indoor commercial space configured with sale counter, comfort chairs, soothing music, and air-conditioning facilities. The second sector is a large extension of semi-outdoor multifunctional space, which 24/7 open to the public with diverse tables and chairs, fans, and lighting facilities. Both sectors cover with wireless access and numerous power sockets for learning and working. The design strategy links commercial space and learning space together that demonstrates the commitment of NUS to share education resource and facilities to all NUS community and society. This action achieves remarkable success in creating a vibrant 24 -hour open campus and maximizing the spatial and facilities utilization. 


\section{Summary}

This paper briefly reviews the Singapore practice on urban

本文简要回顾了新加坡在亚洲高密度人口背景下的城市宜居性和 可持续发展实践, 并总结了促进建成环境和社会福祉的三个核心支柱 （图6）。其一是政府管理机构做出的行政决策决定着城市规划和土 地利用的方向, 决策包括自然保护、生活-工作-休闲一体化、交通连 接性和公共场所营造。二是专业设计人员通过空间配置保证了环境质 量, 勾勒出了构成城市形态的要素, 其策略包括提升绿色开放空间的 可达性、打造多功能半开放空间和对温度舒适度进行考量, 同时也包 括绿色可持续设计。三是多方利益相关者共同管理协调各方利益和项 目安排, 涵盖全天候开放与维护规则、公共利益和私人利益的博亦、 常规和临时项目设置等问题。 liveability and sustainable development in the context of highdense Asian context. Three core pillars are summarized for promoting built environment and social well-being (Fig. 6). First, policy-making from the administrative governances determines the direction of urban planning and land use, which includes natural conservation, live-work-play integration, transportation connectivity, and public place-making.

Second, spatial arrangement from the design professionals formulates the environmental quality and essential factors of urban morphology, such as the accessibility of green open space, multi-functional semi-open space and thermal comfort considerations, as well as green and sustainable design. Third, site management from the multi-party stakeholders coordinates the diverse interests and program settings. It covers the issues 24/7 openness and maintenance, public good and private interests, regular and provisional program settings.

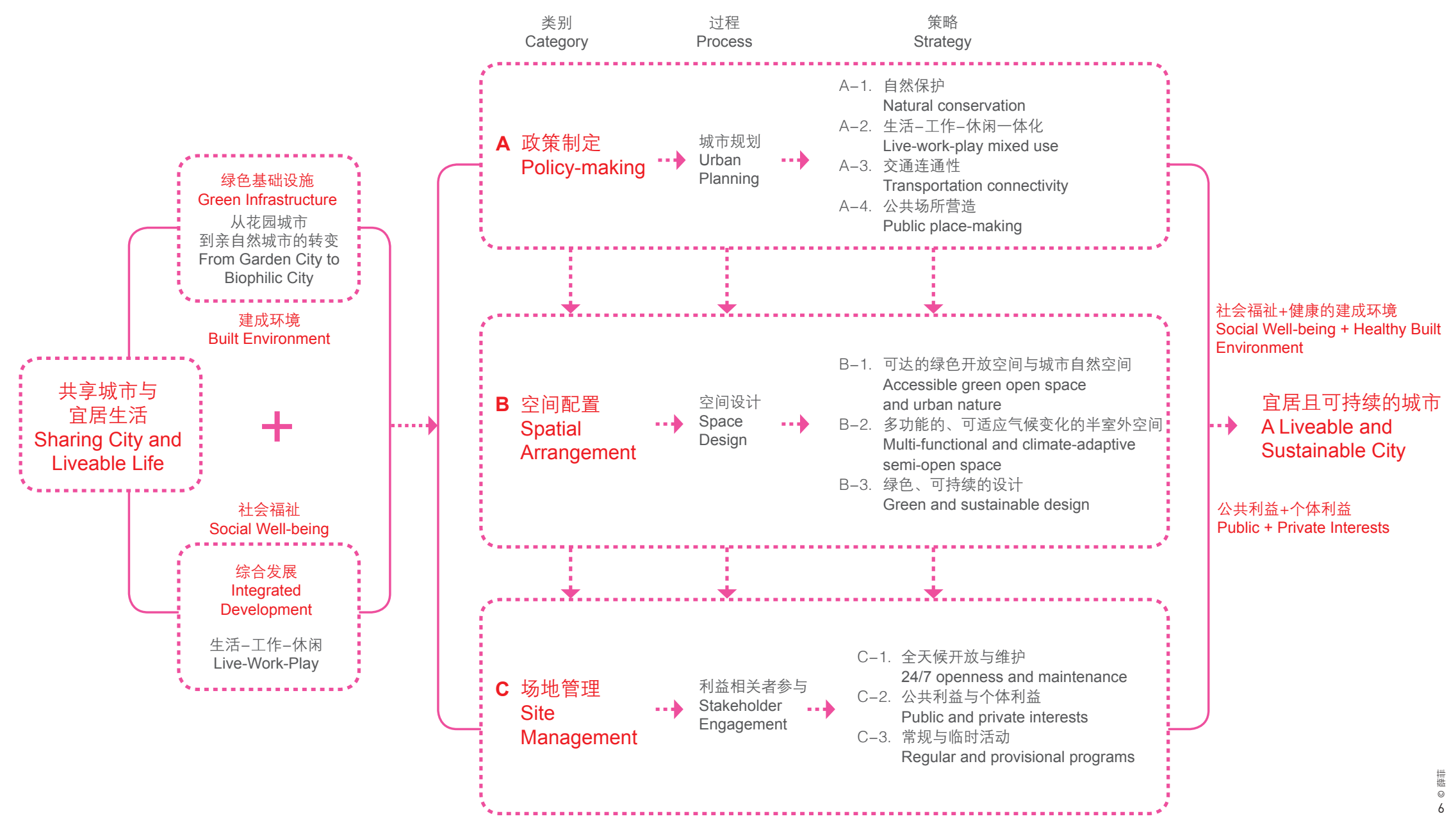


在追求社会和谐与平等的新时代, 共享空间和宜居生活显得尤为 重要。新加坡的实践经验表明, 高密度本身并不是影响人们生活满意 度的主要障碍 ${ }^{[2][21]}$ 。相反, 它为由传统商业模式向新型 “共享经济” ${ }^{[1]}$ 转型提供了机遇。如今, 我们着眼于健康和可持续的生活方式, 这已 然形成并推动了各项可促进健康和提高生活质量的策略的实施。本文 基于对新加坡实践中的共享空间和城市宜居性的探讨，分析了新加坡 如何通过决策制定、空间配置和场地管理三个层面来促进城市未来更 加美好繁荣。
Sharing space and liveable life are particularly paramount regarding the social harmony and equity in the new era. Learning from Singapore experience, it is verified that high density per se is not the primary obstacles for life satisfaction $^{[2][21]}$. Instead, it turns to the opportunity to accommodate the transformation from the traditional commercial model to the new "sharing economy." "1] Today, we are looking at the lifestyles of health and sustainability, which has emerged to frame and facilitate the implementation of health promotion and quality of life improvement. The research of sharing space and urban liveability in Singapore practices addresses policy-making, spatial arrangement, and site management for a flourishing city future. LAF

\section{REFERENCES}

[1] McLaren, D., \& Agyeman, J. (2015). Sharing Cities: A Case for Truly Smart and Sustainable Cities. Cambridge, Massachusetts: MIT Press.

[2] Howley, P., Scott, M., \& Redmond, D. (2009). Sustainability versus Liveability: An Investigation of Neighbourhood Satisfaction. Journal of Environmental Planning and Management, 52(6), 847-864.

[3] Economist Intelligence Unit, \& Siemens. (2012). The Green City Index: A Summary of the Green City Index Research Series (p. 47). Munich: Siemens AG.

[4] Mercer. (2012). 2012 Quality of Living Worldwide City Rankings Survey. International HR Adviser, 33-36. Retrieved from http://issuu. com/internationalhradviser/docs/ihra winter_2012_combined?e $=3256935 / 3207748$

[5] Urban Land Institute, \& Center for Liveable Cities. (2013). 10 Principles for Liveable High-Density Cities: Lessons from Singapore (p. 91). Retrieved from http:// americas.uli.org/wp-content/uploads/sites/125/ULIDocuments/10PrinciplesSingapore.pd

[6] Kabisch, N., Strohbach, M., \& Haase, D. (2015). Internal Project Report on Inventory of Urban Green Space Demand for the Two Scale Levels, Ulls and European Urban Atlas Cities Report Milestone NR MS 24 (p. 16). Berlin: Humbold University Berlin.

[7] Khoo, T. C., \& Guo, R. (2017). Making Singapore a Liveable and Sustainable City: Our Urban Systems Approach. In C. K. Heng (Ed.), 50 Years of Urban Planning in Singapore lpp. 81100). Singapore: World Scientific Publishing Company.

[8] Heng, C. K. (Ed.). (2017). 50 Years of Urban Planning in Singapore. Singapore: World Scientific Publishing Company.

[9] Pheng, L. S., \& Chen, N. W. (2011). Integration Management for Green Business to achieve Sustainability and Buildability. IBA Business Review, 6(1), 27-50.

[10] Barnard, T. P., \& Heng, C. (2014). A City in a Garden. In T. P. Barnard (Ed.), Nature Contained: Environmental Histories of Singapore (pp. 281-306). Singapore: NUS Press.

[11] Lee, K. Y. (2000). From Third World to First: The Singapore Story: 1965-2000. Singapore: HarperCollins.

[12] Kellert, S. R., \& Wilson, E. O. (Eds.). (1993). The Biophilia Hypothesis. Washington, D.C.: Island Press.

[13] Center for Liveable Cities, \& Civil Service College. (2014). Liveable and Sustainable Cities: A Framework. Singapore: National Library Board. Retrieved from http://www.clc.gov. sg/documents/books/CLC_CSCLiveable\&SustainableCities. pdf

[14] Beatley, T. (2012). Singapore: How to Grow a High-Rise City in a Garden. Site Lines, 8(1), 14-17.

[15] National Population and Talent Division. (2013). Singapore Population White Paper 2013 (p. 76). Singapore: Singapore Population White Paper.
[16] Ministry of National Development. (2013). Land Use Plan to Support Singapore's Future Population. Singapore: Ministry of National Development. Retrieved from http://www.mnd. gov.sg/landuseplan/e-book/

[17] Ministry of the Environment and Water Resources, \& Ministry of National Development. (2015). Sustainable Singapore Blueprint 2015 (p. 112). Retrieved from http://www.mewr.gov. sg/ssb/files/ssb2015.pdf

[18] Danielsen, K. A., \& Lang, R. E. (2012). Live Work Play: New Perspectives on the Downtown Rebound. disP - The Planning Review, 46(180), 91-105. doi: 10.1080/02513625.2010.10557066

[19] Kent, J., Thompson, S., \& Jalaludin, B. (2011). Healthy Built Environments: A Review of the Literature. Sydney: Healthy Built Environments Program, City Futures Research Centre, The University of New South Wales. Retrieved from https:// core.ac.uk/download/pdf/30677828.pdf

[20] Carlson, C., Aytur, S., Gardner, K., \& Rogers, S. (2012). Complexity in Built Environment, Health, and Destination Walking: A Neighborhood-Scale Analysis. Journal of Urban Health, 89(2), 270-284. doi:10.1007/s11524-011-9652-8

[21] Ng, J. (2013, September). High-density Sustainability and Liveability - The Case of Hong Kong. Paper presented at the Sustainable Building 2013 Hong Kong Regional Conference, Urban Density and Sustainability, Hong Kong. 